\title{
PERTUMBUHAN DAN TINGKAT KEMATANGAN GONAD IKAN KERAPU BATIK (Epinephelus polyphekadion) HASIL BUDIDAYA
}

\author{
Ketut Maha Setiawati ${ }^{\mathrm{a}, *}$, Regina Melianawati ${ }^{\mathrm{a}}$ \\ ${ }^{a}$ Balai Besar Riset Budidaya Laut dan Penyuluhan Perikanan \\ Banjar Dinas Gondol, Ds Penyabangan, Gerokgak, Buleleng, Bali, Indonesia \\ *Koresponden penulis : mahasetiawati@yahoo.com
}

\begin{abstract}
Abstrak
Ikan kerapu batik merupakan jenis ikan laut yang bernilai ekonomis tinggi, sehingga budidaya terhadap ikan ini perlu dilakukan. Dua parameter yang penting dalam budidaya adalah pertumbuhan untuk mengetahui kondisi individu ikan dan tingkat kematangan gonad (TKG) yang menunjukkan perkembangan gonad ikan. Kedua hal tersebut merupakan indikator yang penting untuk evaluasi keberhasilan suatu budidaya. Penelitian ini bertujuan untuk mengetahui pertumbuhan, panjang dan berat ikan kerapu batik hasil budidaya serta perkembangan tingkat kematangan gonadnya selama pemeliharaan. Penelitian menggunakan 2 buah bak fiberglass volume $1.000 \mathrm{~L}$, yang masing-masing bak diisi dengan 20 ekor ikan dengan ukuran panjang awal 8,96 $\pm 1,5 \mathrm{~cm}$ dan berat tubuh $13 \pm 2 \mathrm{~g}$. Pemeliharaan dilakukan selama 19 bulan dan selama itu ikan diberi pakan pellet. Variabel yang diamati adalah pertumbuhan ikan yang diukur dari panjang dan berat tubuhnya, serta tingkat kematangan gonad dan diameter telurnya. Hasil menunjukkan bahwa pada akhir penelitian, panjang ikan mencapai $16,0-30,9 \mathrm{~cm}$, terbanyak pada kisaran panjang 22,0-24,9 cm $(37,7 \%)$, dan berat tubuhnya berkisar 60-484 g. Pertumbuhan berat ikan lebih cepat daripada pertumbuhan panjangnya. Gonad ikan mulai berkembang pada panjang 19,0-21,9 cm dengan TKG I (54,5\%), II (27,5\%) dan III (18,0\%). Pada akhir penelitian, ikan dengan panjang 28,0-30,9 cm sudah mencapai TKG IV (60\%). Kisaran diameter telur yang dominan pada TKG I, II, III dan IV, masing-masing adalah 10,0-35,9 $\mu \mathrm{m}$ (89,5\%), 36,0-61,9 $\mu \mathrm{m}(73,2, \%), 36,0-61,9 \mu \mathrm{m}(56,1 \%)$ dan 30,0-61,9 $\mu \mathrm{m}(58,8 \%)$. Hasil ini menunjukkan bahwa ikan kerapu batik hasil budidaya yang dipelihara dalam bak pemeliharaan dapat mengalami pertumbuhan dan perkembangan tingkat kematangan gonad.
\end{abstract}

Kata kunci: diameter telur, ikan kerapu batik, pertumbuhan, tingkat kematangan gonad

\begin{abstract}
Camouflage grouper is a marine fish that has high economical value, so the culture of this species needs to be done. Two important parameters in culture are growth to determine the condition of fish and the level of gonad maturity (TKG) which shows the development of fish gonads. Both of those are important indicators to evaluate the success of culture. This study was aimed to determine the growth, length and weight of cultivated camouflage grouper and the development of gonad maturity level during the rearing period. The study was used 2 pieces of 1,000 L fiberglass tanks. Each tank contained 20 fishes with initial length of 8.96 $\pm 1.5 \mathrm{~cm}$ and body weight of $13 \pm 2 \mathrm{~g}$. Rearing was carried out for 19 months. Fish are fed by artificial feed. The observed variables were fish growth which measured by body length and weight, as well as gonad maturity and eggs diameter. The results showed that at the end of the study, fish length reached 16.0-30.9 $\mathrm{cm}$, mostly in the range of length $22.0-24.9 \mathrm{~cm}(37.7 \%)$ and body weight ranged from 60 to $484 \mathrm{~g}$. Growth of weight is faster than growth in length. Gonad of fishess began to develop at 19.0-21.9 cm length with TKG I (54.5\%), II (27.5\%) and III (18.0\%). At the end of study, fish with length of $28.0-30.9 \mathrm{~cm}$ had reached TKG IV (60\%). The dominant eggs diameter in TKG I, II, III and IV, respectively, were 10.0-35.9 $\mu \mathrm{m}(89.5 \%), 36.0-61.9 \mu \mathrm{m}(73.2, \%), 36.0-61.9 \mu \mathrm{m}(56.1 \%)$ and 30.0-61.9 $\mu \mathrm{m}(58.8 \%)$. These results indicated that the cultivated camouflage grouper that were rearing in a tank can grow and has development of the gonad maturity level.
\end{abstract}

Keywords: eggs diameter, camouflage grouper, growth, gonad maturity level 


\section{PENDAHULUAN}

Ikan kerapu merupakan salah satu jenis ikan laut di perairan Indonesia yang bernilai ekonomis tinggi dan merupakan komoditas ekspor ke beberapa negara di kawasan Asia [1], terutama Hongkong yang merupakan negara tujuan ekspor utama ikan kerapu hidup di dunia [2]. Ikan kerapu batik (Epinephelus polyphekadion) merupakan salah satu jenis ikan kerapu yang termasuk komoditas ekspor dengan nilai tinggi [3]. Saat ini harga ikan kerapu batik sudah dapat mencapai ratusan ribu hingga jutaan per ekornya, dengan kisaran Rp 100.000 hingga Rp 1.000.000, karena keberadaannya yang semakin langka [4]. Oleh karenanya, kegiatan budidaya terhadap ikan kerapu semakin digalakkan sejalan dengan bertambahnya permintaan ikan kerapu untuk memenuhi kebutuhan, baik di dalam negeri maupun untuk ekspor [1].

Pembenihan ikan kerapu batik sudah berhasil dilakukan di Balai Besar Riset Budidaya Laut dan Penyuluhan Perikanan (BBRBLPP). Induk ikan kerapu batik yang berasal dari alam sudah dapat didomestikasi dalam bak beton hingga berhasil memijah dan menghasilkan telur yang fertil dan larvanya dapat dipelihara hingga menjadi juvenil [5]. Benih yang dihasilkan tersebut selanjutnya tetap dipelihara hingga menjadi calon induk dan induk yang dapat memijah. Terkait dengan tahapan tersebut maka pengetahuan tentang biologi reproduksi ikan yang dibudidayakan sangat penting untuk diketahui karena akan memberikan dasar informasi tentang pengelolaan komoditas tersebut secara berkelanjutan.

Pertumbuhan merupakan indikator yang baik untuk mengetahui kondisi individual maupun populasi ikan, dan dapat didefinisikan sebagai pertambahan ukuran, baik panjang maupun berat dalam satuan waktu [6]. Menurut [7], berat tubuh ikan dapat dianggap sebagai suatu fungsi dari panjang dan biasanya mengikuti hukum kubik yang menunjukkan bahwa berat ikan merupakan pangkat tiga dari panjangnya. Lebih lanjut dijelaskan, pertumbuhan ikan yang mengikuti hukum kubik dapat disebut pertumbuhan isometrik $(b=3)$, sedangkan pertumbuhan yang tidak mengikuti hukum kubik disebut pertumbuhan alometrik $(b \neq 3)$. Masih menurutnya, apabila nilai $\mathrm{b}<3$ artinya pertumbuhan ikan bersifat alometrik negatif, yang berarti pertumbuhan panjangnya lebih cepat dari pertumbuhan berat, sebaliknya apabila nilai $b>3$ artinya pertumbuhan ikan bersifat alometrik positif yang artinya pertumbuhan beratnya lebih cepat dari pertumbuhan panjang. Beberapa faktor yang mempengaruhi pertumbuhan ikan diantaranya adalah ketersediaan pakan dalam jumlah yang cukup [8] dan kualitas yang baik [9, 10], serta kondisi lingkungan yang sesuai [11].

Reproduksi merupakan hal yang penting untuk proses regenerasi. Tingkat kematangan gonad (TKG) merupakan suatu parameter dasar dari biologi reproduksi yang penting untuk diketahui dalam suatu populasi ikan. TKG itu sendiri merupakan suatu tahap tertentu perkembangan gonad sebelum dan sesudah ikan memijah dan selama proses itu berlangsung maka sebagian besar hasil metabolisme akan tertuju pada perkembangan gonad. Lebih lanjut dijelaskannya, waktu dan ukuran pertama kali matang gonad pada setiap spesies ikan tidak selalu sama [7].

Berdasarkan proses perkembangan gonadnya, ikan kerapu termasuk jenis ikan hermaprodit protogini, yang berarti ikan betina dewasa akan mengalami perubahan kelamin menjadi jantan [12]. Jadi, ikan kerapu memulai siklus reproduksinya sebagai ikan betina kemudian berubah menjadi ikan jantan yang fungsional. Hasil penelitian [13] menunjukkan bahwa ikan kerapu batik yang diperoleh dari hasil penangkapan di alam, untuk betina yang sudah dewasa fungsional berukuran panjang total 33,0-46,4 $\mathrm{cm}$ dengan berat tubuh $0,6-1,5 \mathrm{~kg}$, sedangkan jantan fungsionalnya berukuran di atas $1,5 \mathrm{~kg}$. Hasil penelitian [5] juga menyatakan bahwa ikan kerapu batik betina berukuran lebih kecil dengan panjang total $32-43 \mathrm{~cm}$ dan berat tubuh $0,5-1,8 \mathrm{~kg}$, sedangkan yang jantan berukuran lebih besar dengan panjang total $44-51 \mathrm{~cm}$ dan berat tubuh $1,9-2,5 \mathrm{~kg}$.

Penelitian tentang biologi reproduksi pada ikan kerapu batik yang berasal dari hasil budidaya belum banyak dilakukan. Perkembangan gonad pada ikan kerapu batik tersebut penting untuk diketahui sebagai salah satu bentuk keberhasilan budidaya. Informasi 
tersebut juga sangat mendukung ketersediaan induk kerapu batik yang saat ini banyak diperlukan dalam program hibridisasi ikan kerapu [14]. Oleh karenanya, penelitian ini bertujuan untuk mengetahui pertumbuhan, panjang dan berat ikan kerapu batik hasil budidaya serta perkembangan tingkat kematangan gonad dan diameter telurnya selama pemeliharaan.

\section{MATERI DAN METODE}

Penelitian ini dilakukan di Balai Besar Riset Perikanan Budidaya Laut dan Penyuluhan Perikanan (BBRBLPP) Gondol. Hewan uji yang digunakan dalam penelitian ini adalah 40 ekor ikan kerapu batik yang berasal dari hasil pembenihan di BBRBLPP, berumur 19 bulan, dengan ukuran panjang 8,9 $\pm 1,5 \mathrm{~cm}$ dan berat tubuh $13 \pm 2 \mathrm{~g}$.

Penelitian dilakukan dengan menggunakan 2 buah bak fiberglass yang masing-masing bervolume $1.000 \mathrm{~L}$. Jumlah ikan dalam setiap bak 20 ekor. Pemeliharaan dilakukan dengan sistem air mengalir dengan pergantian air sebesar 300\%/hari. Selama pemeliharaan ikan diberi pakan buatan komersil yang memiliki kandungan protein sebesar 43\%. Sekali setiap bulan ikan direndam dalam air tawar selama 5 menit untuk menghilangkan ektoparasit yang mungkin menempel pada permukaan tubuh ikan, seperti Benedenia dan lintah.

Variabel penelitian meliputi panjang,berat, tingkat kematangan gonad dan diameter telur yang diamati secara histologi. Panjang ikan diukur dengan menggunakan penggaris, sedangkan penimbangan berat ikan dilakukan dengan timbangan digital Scout Pro dengan ketelitian 1 g. Hasil pengukuran panjang dan berat tersebut digunakan pula untuk menganalisis hubungan panjang berat sesuai dengan rumus [15] sebagai berikut:

$$
W=a L^{b}
$$

dimana:

W: berat $(\mathrm{g})$,

L: panjang $(\mathrm{cm})$,

a dan $\mathrm{b}$ : konstanta.

Pembuatan preparat histologi dilakukan di laboratorium biologi BBRBLPP dengan mengikuti metode yang dilakukan di CISRO Marine Research Laboratory, Cleaveland, Australia [16]. Selanjutnya preparat tersebut diamati dengan mikroskop. Kriteria tingkat kematangan gonad mengacu pada $[17,18]$ yang membagi perkembangan gonad menjadi 6 tingkat (Tabel 1). Pengukuran diameter telur juga dilakukan dengan mikroskop Nikon eclipse E600 yang dilengkapi dengan camera Nikon DXM 1200F. Hasil pengamatan tersebut kemudian dianalisis secara kualitatif dan ditampilkan dalam bentuk gambar.

Tabel 1. Kriteria tingkat kematangan gonad ikan kerapu $[17,18]$

\begin{tabular}{|l|l|}
\hline Tingkat I & $\begin{array}{l}\text { Belum berkembang (terdapat } \\
\text { oogonia di dalam gonad yang } \\
\text { diamati) }\end{array}$ \\
\hline Tingkat II & $\begin{array}{l}\text { Oogonia berkembang menjadi } \\
\text { oosit. Sitoplasma berwarna ungu. }\end{array}$ \\
\hline Tingkat III & $\begin{array}{l}\text { Terbentuk kortikel alveoli, korion } \\
\text { mulai terbentuk }\end{array}$ \\
\hline Tingkat IV & $\begin{array}{l}\text { Pembentukan kuning telur tidak } \\
\text { bisa diberi pewarnaan, korion } \\
\text { semakin jelas }\end{array}$ \\
\hline Tingkat V & $\begin{array}{l}\text { Matang/hidrasi (kuning telur } \\
\text { berwarna kuning secara homogen; } \\
\text { oosit terhidrasi, perkembangan } \\
\text { oosit telah sempurna) }\end{array}$ \\
\hline Tingkat VI & Salin (oosit mengalami atresia) \\
\hline
\end{tabular}

\section{HASIL DAN PEMBAHASAN}

\section{Pertumbuhan}

Hasil penelitian menunjukkan bahwa ikan kerapu batik setelah dipelihara 19 bulan memiliki hubungan panjang dan berat dengan persamaan $\mathrm{y}=0,0068 \mathrm{x}^{3,3088}$ dan korelasi $(\mathrm{r})=$ 0,949 (Gambar 1). Hasil tersebut menunjukkan bahwa selama masa pemeliharaan tersebut, ikan kerapu batik mengalami pertambahan berat yang lebih cepat dibandingkan pertambahan panjangnya, yang ditunjukkan dengan nilai $b=3,3088$. Menurut [7], apabila nilai b>3 menunjukkan bahwa pertambahan beratnya lebih cepat daripada pertambahan panjangnya. Dari Gambar 1 tersebut juga dapat diketahui adanya hubungan yang erat antara panjang total dan berat tubuh ikan kerapu batik, yang ditunjukkan dengan nilai r yang mendekati 1 . 


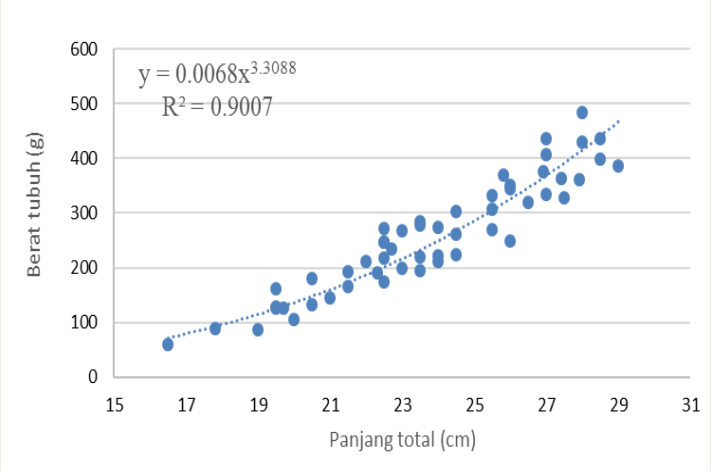

Gambar 1 Hubungan panjang dan berat ikan kerapu batik pada akhir penelitian

Kisaran ukuran panjang total ikan kerapu batik pada akhir penelitian ditunjukkan pada Gambar 2. Setelah dipelihara selama 19 bulan, diperoleh ikan kerapu batik dengan kisaran panjang total 16,0-30,9 $\mathrm{cm}$, dengan kisaran terbanyak pada panjang total $22,0-24,9 \mathrm{~cm}$ $(37,7 \%)$.

\section{Tingkat Kematangan Gonad}

Gonad ikan kerapu batik mulai berkembang pada kisaran ukuran panjang total 19,0-21,9 cm (Gambar 3). Pada ikan ukuran tersebut, gonad sudah mencapai Tingkat Kematangan Gonad (TKG) I, II dan III.

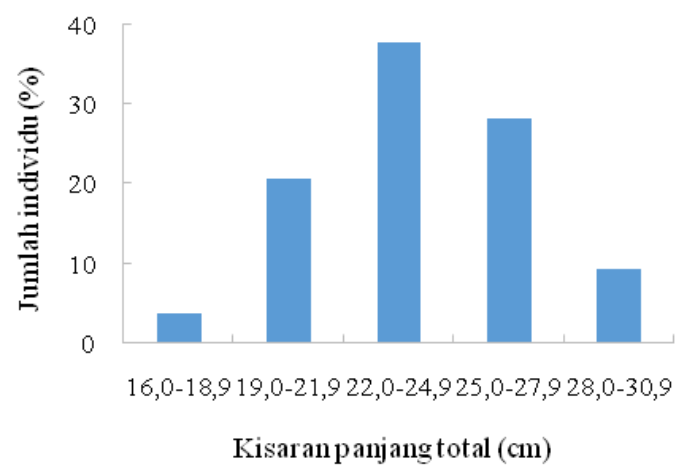

Gambar 2 Persentase kisaran panjang total kerapu batik pada akhir penelitan

Kisaran ukuran berat tubuh ikan kerapu batik pada akhir penelitian ditunjukkan pada Gambar 3. Setelah dipelihara selama 19 bulan, diperoleh ikan kerapu batik dengan kisaran berat tubuh 60- $384 \mathrm{~g}$, dengan kisaran terbanyak pada berat tubuh 145-229 g $(29,9 \%)$.

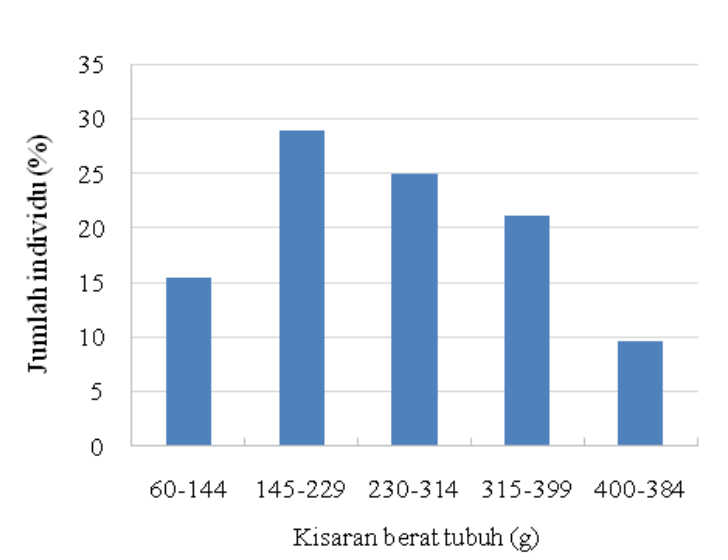

Gambar 3 Persentase kisaran berat tubuh kerapu batik pada akhir penelitan

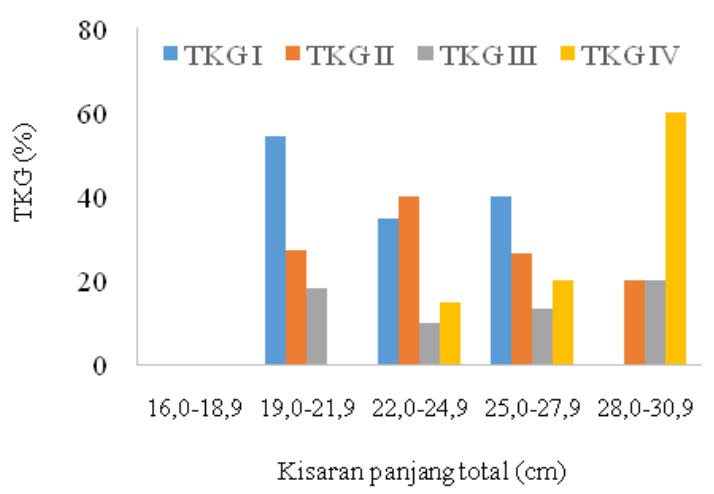

Gambar 4 Tingkat kematangan gonad ikan kerapu batik pada kisaran panjang total berbeda

Perkembangan tingkat kematangan gonad ikan kerapu batik dari TKG I sampai IV ditunjukkan pada Gambar 5. Pada TKG 1 masih berukuran kecil dengan sitoplasma masih berwarna biru. Pada TKG II sel telur membesar. TKG III mulai nampak kortikel alveoli, dinding sel telur terlihat jelas. Pada TKG IV muncul vitelogenin berwarna merah yang menandakan sudah terbentuknya kuning telur serta dinding sel telur yangterlihat semakin jelas.

Hubungan antara panjang total dengan TKG menunjukkan nilai korelasi $\mathrm{r}=0,42$ (Gambar 6), sedangkan hubungan antara berat dengan TKG memiliki nilai $\mathrm{r}=0,47$ (Gambar 7). Hal ini menunjukkan bahwa korelasi antara panjang total dan berat terhadap TKG tergolong sedang. Korelasi tersebut menunjukkan bahwa semakin bertambahnya ukuran panjang dan berat tubuh ikan tidak selalu diikuti dengan peningkatan TKG. Hal ini disebabkan karena dijumpai pada ikan 
dengan ukuran kisaran panjang dan berat yang sama tidak mempunyai TKG yang sama, seperti yang ditunjukkan pada Gambar 4. Terjadinya hal tersebut dapat disebabkan oleh kondisi lingkungan dimana ikan tersebut hidup, ada tidaknya ketersediaan makanan, kondisi suhu dan salinitas serta kecepatan pertumbuhan ikan itu sendiri [19].

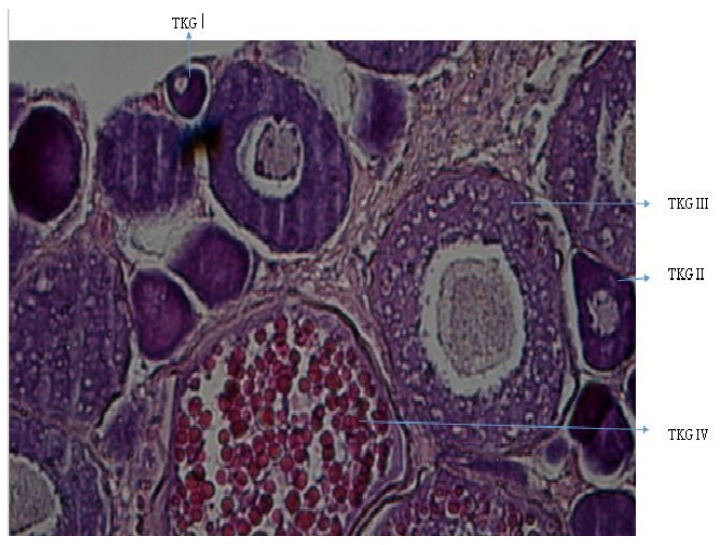

Gambar 5 Perkembangan tingkat kematangan gonad (TKG) I, II, III, IV

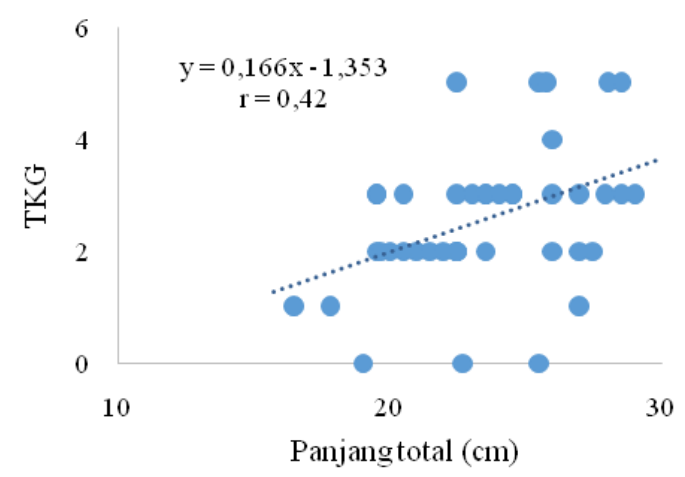

Gambar 6 Hubungan antara panjang total dan TKG

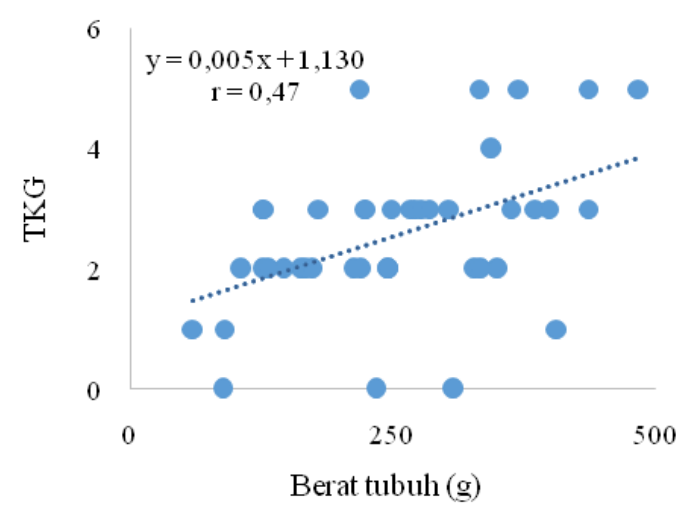

Gambar 7 Hubungan antara berat tubuh dan TKG
Hasil penelitian [20] menunjukkan bahwa gonad pada ikan kerapu batik betina mulai ditemukan pada kisaran ukuran panjang $16,0-17,9 \mathrm{~cm}$ dan paling banyak pada ukuran panjang standar 24,0-27,9 cm, sedangkan gonad jantan mulai terbentuk pada ukuran panjang standar 16,0-17,9 $\mathrm{cm}$ dan terbanyak pada panjang 34,0-37,9 mm. Menurutnya, ikan kerapu batik yang berukuran $38,0 \mathrm{~cm}$ keatas sudah menjadi jantan semua, sedangkan ikan yang berukuran 24,0-37,9 mm tergolong dalam masa transisi. Hasil penelitian menunjukkan bahwa ikan kerapu batik yang produktif untuk jenis betina adalah pada ukuran panjang $50 \mathrm{~cm}$ dengan berat 2,5 $\mathrm{kg}$, sedangkan untuk jantan pada panjang 55 $\mathrm{cm}$ dan berat $4 \mathrm{~kg}$ [21].

Ikan kerapu batik merupakan hermaprodit protogini yang mengalami proses diferensiasi gonad dari fase betina ke fase jantan. Salah satu faktor yang mempengaruhi perubahan tersebut jika rasio jantan dan betina dalam populasi tidak seimbang. Pada penelitian ini, perubahan jenis kelamin tidak terjadi karena ukuran ikan masih tergolong muda belum mencapai TKG $\mathrm{V}$ dan belum produktif. Perubahan kelamin jantan menjadi betina atau betina menjadi jantan pada ikan kerapu akan sangat drastis apabila perbandingan (rasio) kelamin jantan dan betinanya tidak seimbang [22].

\section{Diameter Telur}

Diameter telur pada masing-masing tingkat kematangan gonad menunjukkan bahwa dari TKG I sampai IV terjadi perkembangan ukuran sel telur yang semakin meningkat (Gambar 8). Pada TKG I, diameter telur terbanyak berada pada kisaran 10,0-35,9 $\mu \mathrm{m}(89,5 \%)$ dan sebagian pada kisaran 36,0-61,9 $\mu \mathrm{m}(10,5 \%)$. Pada TKG II, terdapat tiga ukuran diameter telur, yaitu terbanyak pada kisaran 36,0-61,9 $\mu \mathrm{m}(73,2 \%)$, namun masih ada yang berdiameter lebih kecil yaitu 10,0-35,9 $\mu \mathrm{m}(21,4 \%)$ dan juga sudah ada yanglebih besar yaitu mencapai $62,0-87,9$ $\mu \mathrm{m}(5,4 \%)$. Pada TKG III, terdapat 6 tingkatan diameter telur namun yang terbanyak terdapat pada kisaran 36,0-61,9 $\mu \mathrm{m}$ $(56,1 \%)$, sebagian kecil telur sudah ada yang mencapai diameter sebesar 140,0-165,9 $\mu \mathrm{m}$ $(1,7 \%)$. Pada TKG IV, sebagian besar 
diameter telur masih berada pada kisaran $30,0-61,9 \mu \mathrm{m}(58,8 \%)$, namun sudah ada pula yang mencapai diameter telur 166,0-191,9 $\mu \mathrm{m}$ $(1,5 \%)$.

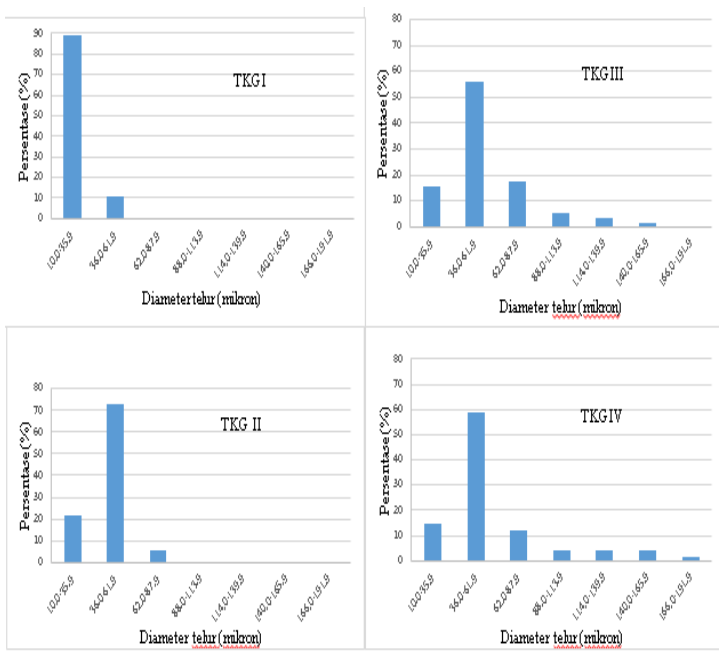

Gambar 8 Diameter telur pada masing-masing tingkat kematangan gonad

Walaupun diameter telur pada masingmasing TKG dapat berkembang, namun terlihat jelas bahwa pada TKG II, III dan IV didominasi oleh diameter telur 36,0-61,9 $\mu \mathrm{m}$, yang menunjukkan bahwa perkembangan tingkat kematangan gonad tidak didukung sepenuhnya dengan perkembangan ukuran telur.

Penyebab terjadinya hal ini diduga karena adanya faktor lingkungan yang kurang mendukung perkembangan gonad ikan, dalam hal ini adalah kedalaman habitat. Di alam, ikan kerapu muda pada umumnya hidup di perairan karang pantai dengan kedalaman 0,53,0 m, dan selanjutnya saat menginjak dewasa akan beruaya ke perairan yang lebih dalam antara 7-40 m [23]. Dalam penelitian ini, pemeliharaan dilakukan dalam bak dengan ketinggian air sekitar $1 \mathrm{~m}$. Berdasarkan hal tersebut, maka faktor kedalaman dalam wadah penelitian yang lebih dangkal dibandingkan kondisi habitat alaminya, diduga menjadi penyebab lambatnya perkembangan ukuran diameter telur.

\section{KESIMPULAN}

Ikan kerapu batik pada umur 19 bulan terdapat pada kisaran panjang 16,0-30,9 cm, dengan berat tubuh 60-484 g. Kisaran terbanyak terdapat pada panjang total 22,0$24,9 \mathrm{~cm}$ sebanyak $37,7 \%$ dari total sampel. Pada kisaran panjang 22,0-24,9 gonad mulai berkembang mencapai TKG IV.

\section{UCAPAN TERIMA KASIH}

Ucapan terimakasih diberikan kepada Bapak Mujimin, Bapak Wiwin dan Made Miniartini sebagai teknisi litkayasa BBRBLPP yang telah membantu pemeliharaan ikan kerapu batik dan pembuatan preparat histologi.

\section{DAFTAR PUSTAKA}

[1] Anonim. (2018, Nov.). Peluang investasi budidaya kerapu skala kecil. [online]. Available: https://bulelengkab.go.id/detail/artikel/p eluang-investasi-budidaya-kerapuskala-kecil-98.

[2] Suhana. (2018, Sept.). Melihat kerapu hidup di pasar Hongkong. [Online]. Available:

https://suhana.web.id/2018/09/14/melih at-kerapu-hidup-di-pasar-hong-kong.

[3] F. McGilvray and T. Chan, "Market and industry demand issues in the live reef food fish trade," SPC Live Reef Fish Information Bulletin, vol. 11, pp. 36-39, 2003.

[4] Anonim. (2017, Nov.) 12 Jenis-jenis ikan kerapu, harga ikan kerapu terbaru. [Online]. Available: https://www.hewan.id/ikan/kerapu.

[5] B. Slamet dan Tridjoko, "Pengamatan pemijahan alami, perkembangan embrio dan larva ikan kerapu batik, Epinephelus microdon dalam bak terkontrol," J. Penelitian Perikanan Indonesia, vol. 3, no. 4, pp. 40-50, 1997.

[6] P.B. Moyle and J. J.Cech, "Fish: An Introduction to Ichthyology," $2^{\text {nd }}$ Edition, Departemen of Wildlife and Fisheries Biology University of California, Davis, Prentice-Hall, Inc., Englewood Cliffs, New Jersey, pp. 309-310, 1988. 
[7] M.I. Effendi, Biologi perikanan, Yayasan Pustaka Nusatama, Yogyakarta, 157 p, 1997.

[8] A. A. Alit dan T. Setiadharma, "Studi frekuensi pemberian pakan yang tepat untuk pendederan juvenil kerapu macan (Epinephelus fuscoguttatus) pada hatcheri skala rumah tangga," Berk. Penel. Hayati Edisi Khusus, vol., 4B, pp. 33-36, 2011.

[9] H. Febrianti, K. Sukarti dan C. A. Pebrianto, "Pengaruh perbedaan sumber asam lemak pada pakan terhadap pertumbuhan ikan bawal bintang (Trachinotus blochii, Lecepede)," J. Aquawarman, vol. 2, no. 1, pp. 24-33, 2016.

[10] S. Rahmaningsih dan A. L. Ari, "Pakan dan pertumbuhan ikan kerapu cantang Epinephellus fuscoguttatuslanceolatus)," Ekologia, vol. 13, no. 2, pp. 25-30, 2013.

[11] S. S. Monalisa dan I. Minggawati, "Kualitas air yang mempengaruhi pertumbuhan ikan nila (Oreochromis sp.) di kolam beton dan terpal," J. of tropical fisheries, vol. 5, no. 2, pp. 526530, 2010.

[12] P. H. Heemstra and J. E. Randall, "FAO species catalogue," vol 16 Grouper of the world. FAO. Rome 382 p. pl XXXI, 1993.

[13] C. S. Tamaru, C. Carlstrom-Trick, W. J. Fitzgerald Jr., H. Ako, "Induced final maturation and spawning of the marbled grouper Epinephelus microdon captured from spawning aggregations in the Republic of Palau, Micronesia," $J$. of the World Aquaculture Society, vol. 27, no. 4, pp. 363-372, 1996.

[14] S. Ismi, Y. N. Asih dan D. Kusumawati, "Peningkatan produksi dan kualitas benih kerapu dengan program hybridisasi," J. Oseanologi Indonesia, vol., 1, no. 1, pp. 1-5, 2014.
[15] W.F. Royce, 1984. "Introduction to the practice of fishery science," Academic Press. California. USA. 423 pp.

[16] Anonim, "Manual of histologycal staining methods," CISRO Marine Research Laboratory, Cleaveland, Australia, 1996.

[17] R. Andamari, "Aspek reproduksi ikan kerapu sunu (Plectropomus leopardus) di perairan Sulawesi dan Maluku," $J$. Penelitian Perikanan Indonesia, vol. 11, no. 7, pp. 7-12, 2005.

[18] R. Andamari, S.B. Moria and I.G.N. Permana, "Aspects of leopard coralgrouper (Plectropomus leopardus) reproduction in Indonesia," Indonesian Aquaculture J., vol. 2, no. 1, pp. 51-57, 2007.

[19] Yustina dan Arnentis, "Aspek Reproduksi Ikan Kapiek (Puntius schwanefeldi Bleeker) di Sungai Rangau-Riau, Sumatra," J, Matematika dan Sains, vol. 7, no. 1, pp. 5-14, 2001.

[20] K. L. Rhodes, R. I. Lewis, R. W. Chapman and Y. Sadovy, "Genetic structure of camouflage grouper, Epinephhelus polyphekadion (Pisces: Serranidae), in the western central Pacific," Marine Biology, vol. 142, pp. 771-776, 2003.

[21] A. Muzaki, S.B.M. Sembiring, I.K. Wardana, Haryanti dan K. Sugama, "Karakter fenotipe dan genotype ikan kerapu hibrida cantik (Epinephelus fuscoguttatus x E. polyphekadion)," Jurnal Riset Akuakultur, vol. 11, no. 1, pp.1-13, 2016.

[22] M. Ghufron, "Budidaya ikan laut di keramba jaring apung, Jakarta," Penerbit Rineka Cipta, 2005.

[23] Sudirman dan Y. Karim, "Ikan kerapu biologi, eksploitasi, manajemen dan budidaya," Yarsif Watampone, Jakarta, 2008. 